Gut, 1987, 28, S1, 9-14

\title{
Effect of monoclonal antibodies to enteroglucagon on ileal adaptation after proximal small bowel resection
}

\author{
M GREGOR, H MENGE, R STÖSSEL, AND E O RIECKEN
}

From the Department of Internal Medicine, Klinikum Steglitz, Freie Universität Berlin, Fed Rep Germany

SUMMARY On the basis of circumstantial clinical and experimental evidence, it has been suggested that enteroglucagon (EG) may act as an enterotrophic factor. This study was undertaken to evaluate the effects of long term in vivo immunoneutralisation of EG, using monoclonal antibodies to EG, on the hyperplastic ileal response after small bowel resection. Nineteen rats had a $70 \%$ proximal resection. A group of 10 rats was given iv $0.5 \mathrm{ml}$ of undiluted hybridoma ascites immediately after the operation and on the 7 th day postoperatively. Furthermore $0.025 \mathrm{ml} /$ day of the same hybridoma ascitic fluid was continuously delivered ip for 14 days via mini-osmotic pumps. The hybridoma ascites was prepared from the clone 23.6B4 synthesising a monoclonal antibody directed toward the $\mathrm{N}$-terminal to central region of the glucagon molecule which showed a marked crossreaction with EG. A control group of 9 rats was given a corresponding amount of antibody-free plasmacytoma ascites $(\mathrm{Ag} \mathrm{8.653)}$ by the same technique. Seven and 14 days postoperatively there was a plasma anti-EG-antibody excess with an excess binding capacity of 84.9 glucagon eq $\mathrm{nM}$ and 88.5 glucagon eq $\mathrm{nM}$ respectively. The three dimensional architecture and the proliferative activity of the ileal remnant were evaluated two weeks postoperatively. Despite a continuous immunoneutralisation of circulating endogenous EG by monoclonal antibodies, the adaptive response of the ileal remnants was of the same magnitude as that seen in the control group. These data do not support the hypothesis that EG is a circulating enterotrophic regulatory peptide.

Indirect evidence suggests that enteroglucagon may act as trophic factor on the intestinal mucosa. ${ }^{12}$ Thus raised circulating levels of enteroglucagon have been reported in various clinical conditions and in experimental animal models which are associated with an increase in intestinal epithelial cell turnover. ${ }^{3}$ For example, the adaptive hyperplastic response of the ileal remnant after proximal bowel resection, is paralleled by an increase in plasma and tissue concentrations of enteroglucagon and both variables are related closely to the extent of the small intestinal resection. ${ }^{4-6}$

In order to gain additional insight into the putative role of enteroglucagon as an enterotrophic regulatory peptide we investigated the influence of long term in vivo immunoneutralisation of circulating enteroglucagon using high titre monoclonal antibodies

Address for correspondence: Dr $\mathbf{M}$ Gregor, Department of Internal Medicine, Klinikum Steglitz, Freie Unversität Berlin, Hindenburgdamm 30, D-1000 Berlin 45, FRG. against enteroglucagon, on the adaptive response of the ileal mucosa to $70 \%$ proximal small intestinal resection. This study was also designed to investigate the hitherto unknown plasma and tissue concentrations of glucagon like peptide 1 (GLP 1) under these conditions. Glucagon like peptide 1 forms a Cterminal extension to, but is separated from, the glucagon precursor glicentin ${ }^{78}$ and shows a close sequence homology to the glucagon molecule. The physiological role of this preproglucagon component peptide, which shows a high conservation in different species, has not yet been elucidated.

\section{Methods}

ANIMALS AND POSTOPERATIVE CARE

Nineteen female Wistar rats, weighing 200-250 g, were used in this study. After a 24 hour fast, the animals were anaesthetised with ether and then underwent a $70 \%$ proximal small bowel resection, 
starting $3 \mathrm{~cm}$ distal to the ligament of Treitz. They were allowed a sugared salt solution, consisting of a mixture of equal parts of $150 \mathrm{mM} \mathrm{NaCl}$ and $300 \mathrm{mM}$ glucose for the first two days postoperatively followed by tap water and a pelleted rat diet $\left(\right.$ Altrumin ${ }^{\mathrm{R}}$ ) ad libitum. The animals were divided into two groups. Group $1(\mathrm{n}=10)$ was given intravenously $0.5 \mathrm{ml}$ undiluted hybridoma ascitic fluid containing the monoclonal antibody $23.6 \mathrm{~B} 4$ immediately after the operation and on the seventh day postoperatively. The hybridoma ascites was prepared from the clone 23.6B4 synthesising a monoclonal antibody directed toward the N-terminal to central region of the glucagon molecule and which showed a complete crossreaction with enteroglucagon. ${ }^{9}$ Furthermore $0.025 \mathrm{ml} / \mathrm{d}$ of the same hybridoma ascites was administered continuously through the Alzet miniosmotic pump, model 2001 (Scientific Marketing Associated, London) which was implanted intraperitoneally immediately after the operation. A new pump was implanted on the seventh day postoperatively. Each pump, which delivered a constant flow of $1.07 \mu \mathrm{l} / \mathrm{h}$ (SD $0.05 \mu \mathrm{l} / \mathrm{h}$ ), was filled with about $240 \mu \mathrm{l}$ hybridoma ascitic fluid. This dose was found in preliminary experiments to give high antibody excess binding over a period of at least seven days. Group 2 rats $(n=9)$ were given a corresponding amount of antibody free plasmacytoma ascites $(\mathrm{Ag}$ 8.653 ) by the same technique and by both routes for the same period of time.

All animals were killed with ether between 1000 and $1100 \mathrm{am}$ two weeks after surgery as adaptive changes in ileal architecture after proximal small bowel resection are known to have reached a plateau at this time. ${ }^{10-12}$ The animals were injected ip vincristine sulphate $(1 \mathrm{mg} / \mathrm{kg}$ body weight $)$ two hours before death. For the morphometric studies, the middle part of the ileal remnants was used. The distal part of the ileal remnants and the colonic midsegments were taken for tissue extraction to measure the intestinal concentrations of enteroglucagon and glucagon like peptide 1 (GLP 1). Blood was taken for GLP 1 radioimmunoassay and measurement of 23.6B4 excess binding activity from the femoral vein immediately before the operation as well as seven and 14 days thereafter.

\section{MORPHOMETRIC MEASUREMENTS}

Microdissection of intestinal segments was carried out as described by Clarke ${ }^{13}$ using the modification of Menge et al ${ }^{10}$ From each sample 10 villus crypt units were isolated at random under the stereomicroscope, for measurement of crypt depth, villus height, villus length at apex and base, and villus width. From these values the villus surface could be calculated. ${ }^{14}$ Ten crypts of the isolated villus crypt units were dissected and the vincristine arrested mitoses per crypt were counted under a binocular microscope.

\section{RADIOIMMUNOASSAY}

The tissue concentrations of enteroglucagon were measured by radioimmunoassay using the monoclonal antibody $23.6 \mathrm{~B} 4$ as described earlier. ${ }^{9}$ Tissue extracts were prepared in water followed by the addition of $0.1 \mathrm{M}$ formic acid, according to Christofides et al. ${ }^{15}$ The monoclonal antibody titres were defined as the dilution of rat plasma that can bind $50 \%$ of 2-3 fmol of ${ }^{125}$ I-glucagon at equilibrium $\left(\mathrm{ABT}_{50}\right)$.

The plasma and tissue levels of GLP 1 were measured by radioimmunoassay using the monoclonal antibody 85.3.7B2 specific for GLP $1 .{ }^{16}$ The assay was capable of detecting plasma concentrations of $6 \mathrm{pmol} / 1$ GLP 1 with $95 \%$ confidence.

NEUTRALISATION OF EXOGENOUS GLUCAGON Two groups of three hour fasted rats (250-300 g body weight) were anaesthetised with sodium pentobarbitone (Nembutal ${ }^{\circledR} ; 60 \mathrm{mg} / \mathrm{kg}$ body weight) and treated as follows: group $1(n=6)$ were allowed to recover for 30 minutes after an intravenous injection of $0.5 \mathrm{ml}$ plasmacytoma 'control' ascites (Ag8.653). Then $0.4 \mathrm{ml}$ blood was collected from the femoral vein for glucose determination and $1.5 \mathrm{nmol}$ porcine glucagon (Eli Lilly), dissolved in $0.4 \mathrm{ml} 0.15 \mathrm{M} \mathrm{NaCl}$ containing $0.1 \%$ human serum albumin (Behring Werke), was given intravenously. After another 15 minutes $0.4 \mathrm{ml}$ blood was drawn for glucose measurement. The plasma samples were assayed for glucose using a glucose oxidase method (Beckman glucose analyser). Group $2(n=6)$ was treated in the same way, the only difference being that $0.5 \mathrm{ml}$ hybridoma ascites 23.6B4 was used instead of the plasmacytoma ascitic fluid.

\section{STATISTICAL ANALYSIS}

Statistical analysis was done using non-parametric methodology (Wilcoxon's test, Whitney Mann U test, Friedman's two-way analysis of variance with multiple comparison according to Wilcoxon and Wilcox). Differences resulting in $p$ values $<0.05$ were considered significant.

\section{Results}

NEUTRALISATION OF EXOGENOUS GLUCAGON The characteristics of the monoclonal antibody 23.6B4 have already been described (9) but are summarised briefly as follows: the antibody was raised against porcine pancreatic glucagon and shows complete crossreactivity with gut glucagon like immunoreactivities. The IgG concentration in the currently used hybridoma ascites was $12.5 \mathrm{mg} / \mathrm{ml}$. Under 


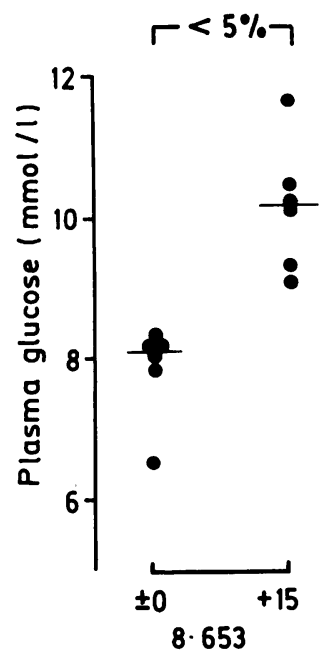

Fig. 1 Effect of immunoneutralisation of exogenous glucagon on plasma glucose levels in 3 hour fasted rats. Group $I(n=6$; closed circles) received plasmacytoma control ascites and $30 \mathrm{~min}$ later $1.5 \mathrm{nmol}$ glucagon. Group 2 $(n=6$; open circles) were injected hybridoma ascites derived from clone 23.6B4 instead of control ascites.

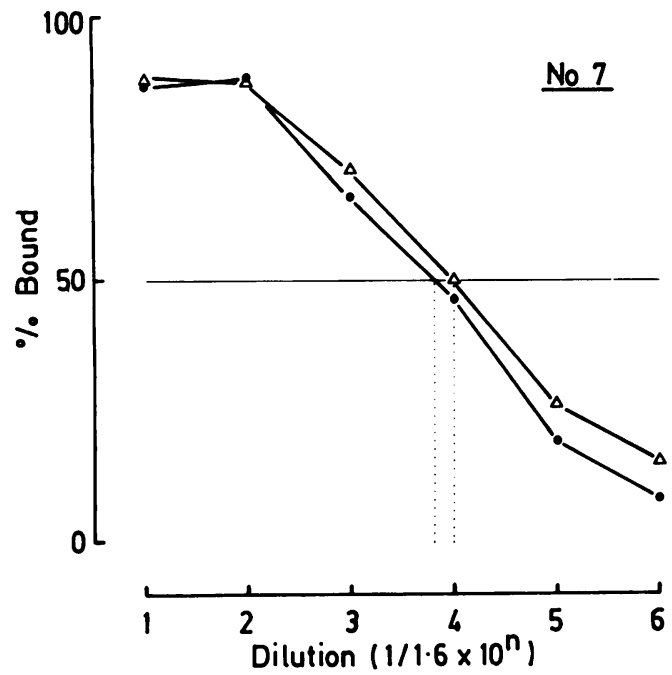

Fig. 2 Titration curve for monoclonal antibody $23.6 \mathrm{~B} 4$ in rat plasma (rat no 7) on day 7 (closed circles) and day 14 (open triangles) postoperatively. Fluids were diluted in assay buffer. The specifically bound tracer was expressed as per cent bound fraction. The horizontal line indicates the $50 \%$ binding for calculation of antibody titre.

standard assay conditions, the $50 \%$ binding titre was $1 / 2 \cdot 1 \times 10^{7}$. The hybridoma ascites consisted of monoclonal antibodies with an avidity of $7.2 \times 10^{6} \mathrm{M}^{-1}$ and a binding capacity of 189 glucagon $\mathrm{eq} / \mu \mathrm{mol}$, as calculated by Scatchard analysis.
Table. Morphometric data of mucosal structure in the ileal remnant after $70 \%$ proximal resection following administration of either plasmacytoma control ascites (1) or hybridoma ascites (2). Results are expressed as means $\pm S E M$ 's.

\begin{tabular}{|c|c|c|c|}
\hline Ileum & $\begin{array}{l}(1) \\
\mathrm{Ag} 8.653 \\
(n=9)\end{array}$ & $\begin{array}{l}(2) \\
23.6 B 4 \\
(n=10)\end{array}$ & \\
\hline Villus height $(\mu \mathrm{m})$ & $371 \pm 13 \cdot 5$ & $396 \pm 22 \cdot 1$ & ns \\
\hline Villus surface $\left(\mathrm{mm}^{2}\right)$ & $0.26 \pm 0.01$ & $0.27 \pm 0.02$ & ns \\
\hline Crypt length $(\mu \mathrm{m})$ & $243 \pm 10 \cdot 0$ & $229 \pm 13 \cdot 1$ & ns \\
\hline Mitoses/crypt/2h & $24 \pm 1 \cdot 7$ & $36 \pm 3 \cdot 6$ & $<0.01$ \\
\hline
\end{tabular}

The glucagon injection in the group B rats given normal control plasmacytoma ascites, caused a significant rise in blood glucose concentration whereas no significant change was found in the hybridoma ascites-treated animals (Fig. 1).

PLASMA ANTIBODY CONCENTRATION AND MORPHOMETRIC DATA AFTER ADMINISTRATION OF MONOCLONAL ANTIBODIES TO RESECTED RATS

The repeated intravenous injections together with the intraperitoneal administration of high titre hybridoma ascites resulted 7 and 14 days after small bowel resection in high antibody binding to ${ }^{125} \mathrm{I}$-glucagon (Fig. 2). Antibody was present with a mean excess antibody titre of $1 / 9500$ on day 7 (range $1 / 5300$ 23000 ), and of $1 / 11000$ on day 14 (range $1 / 6400$ $1 / 18000$ )-corresponding to a mean excess binding capacity of 84.9 glucagon eq/nM (day 7) and 88.5 glucagon $\mathrm{eq} / \mathrm{nM}$ (day 14 ) respectively.

The results of the morphometric analyses done two weeks after small bowel resection, are given in the Table. There was no significant difference in the architecture of the hyperplastic mucosa in the ileal remnant between the two groups of animals. There was however a significant increase in the number of mitoses per crypt per two hours for the same intestinal segment in the monoclonal antibody treated animals when compared with the group of rats which had been injected with control hybridoma ascites $(\mathrm{p}<0.01)$.

\section{HORMONAL CONCENTRATIONS AFTER}

ADMINISTRATION OF MONOCLONAL ANTIBODIES IN THE RESECTED RATS

There were no significant differences in the tissue concentrations of enteroglucagon in the small intestinal remnant and the midcolonic segment between the two treatment groups (Fig. 3). The same was true for glucagon like peptide 1 (GLP 1), which was found in the same parts of the intestine and in nearly equimolar concentrations, as enteroglucagon (Fig. 4). In contrast, the basal plasma concentrations of 


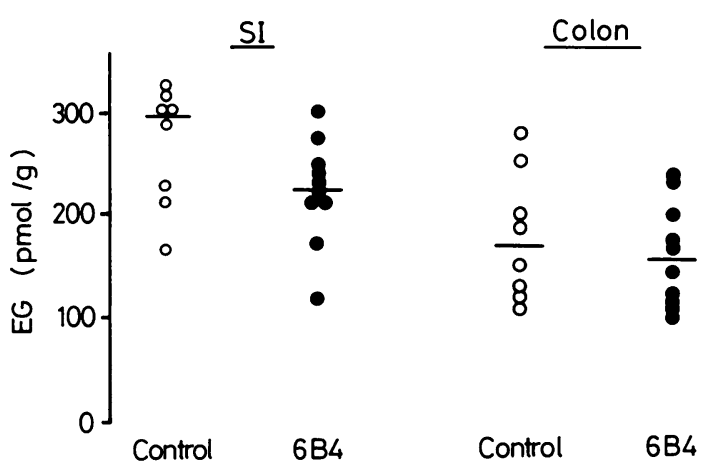

Fig. 3 Tissue concentrations of enteroglucagon in ileal remnant and colonic midsegment after $70 \%$ proximal small bowel resection. Open circles: plasmacytoma control ascites treated group. Closed circles: Hybridoma ascites treated group.

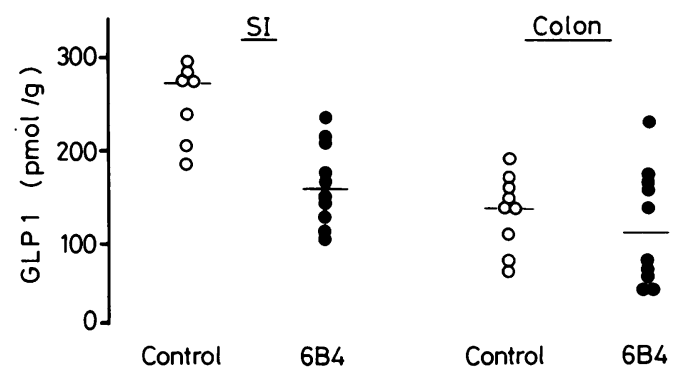

Fig. 4 Tissue concentrations of GLP 1 in the ileal remnant and colonic midsegment after small bowel resections Open circles: plasmacytoma control ascites treated group. Closed circles: hybridoma ascites treated group.

GLP 1 increased after small bowel resection (Fig. 5). This increase was significant in the antibody-treated group of rats seven days after the operation $(p<0.05)$. Furthermore, at this time the basal plasma concentrations of GLP 1 were significantly more increased in the monoclonal antibody treated group of animals when compared with the control group $(\mathrm{p}<0.01)$.

\section{Discussion}

The technique of in vivo immunoneutralisation of endogenous circulating regulatory peptides by intravenous or intraperitoneal injection of specific antisera has been used to explore the physiological role of several gastroenteropancreatic peptides including insulin, gastrin, somatostatin, gastric inhibitory polypeptide (GIP), secretin, and glucagon. ${ }^{17-30}$ Furthermore, monoclonal antibodies have been developed against progesterone to prevent pregnancy by passive immunisation with these antibodies. ${ }^{31}$ Such mono-

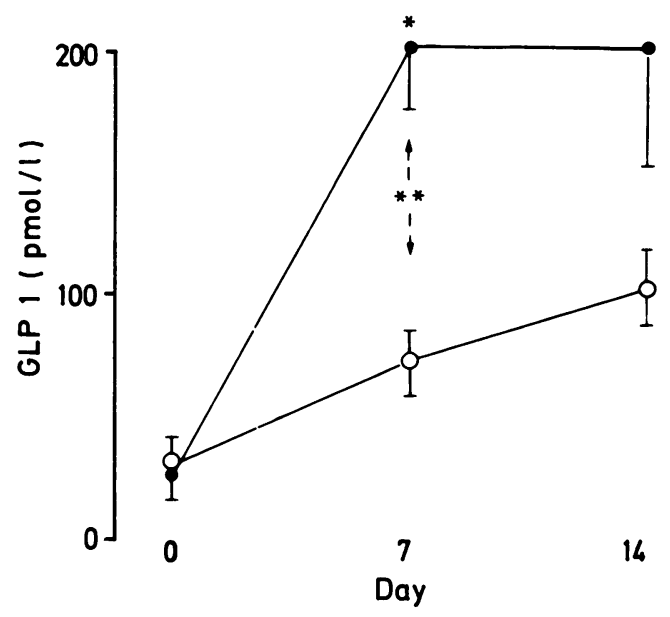

Fig. 5 Basal plasma concentrations of GLP 1 before $70 \%$ proximal small bowel resection (day 0), seven days after resection (day 7) and 14 days after resection (day 14). Open circles: plasmacytoma control ascites treated group. Closed circles: hybridoma ascites treated group. Results are given as means and standard error of the mean. *indicates the level of significance in relation to concentrations before resection (day 0 ) and ${ }^{*} s$ within the broken arrows that between the two different treatment groups at day 7. Levels of significance: ${ }^{*} 0 / 7: p<0.05,{ }^{* *} p<0.01$.

clonal antibodies are, theoretically, superior to polyclonal antisera for immunoneutralisation of circulating peptides because of the constant supply of large quantities of homogenous antibodies with precise and well defined epitope specificity, appropriate affinity, and biological activity.

Using this technique with newly developed monoclonal immunoreagents for continuous immunoneutralisation of circulating glucagon and enteroglucagon, we found an adaptive response in the ileal remnant which was no different from that seen in the plasmacytoma treated control group of rats with respect to mucosal architecture. In fact, the adaptive response was actually greater as judged by the increased number of mitoses per crypt. The tissue concentrations of enteroglucagon and GLP 1 were also comparable in the two treatment groups but were increased in the ileal remnant when compared to those seen in non-resected or sham operated rats. ${ }^{911}$

Glucagon like peptide 1 is a C-terminal extension of enteroglucagon in the common preproglucagon molecule and has been found in a single molecular form in gut tissue extracts by radioimmunoassay using the monoclonal antibody 85.3.7B2. ${ }^{16}$ Taken together with our present data of equimolar tissue concentrations of these two peptides, this suggests that GLP 1 tissue levels might be used as an index of the rate of synthesis of enteroglucagon. For the same 
reason, the raised plasma levels of GLP 1 found seven and 14 days after proximal small bowel resection are indicative of the well known increase in plasma enteroglucagon concentrations in this situation. ${ }^{511}$ The even greater increase in GLP 1 during immunoneutralisation of enteroglucagon than in the control group, may, therefore, reflect an even more stimulated enteroglucagon synthesis rate in the small intestinal L-cells, following depletion of enteroglucagon in plasma.

The monoclonal antibody 23.6B4 used in the present study is directed towards the antigenic determinant which is in the $\mathrm{N}$-terminal to central region of the glucagon molecule. This represents the immunoreactant common to all gut GLIs and glucagon, in different species such as man, the rat and the pig. ${ }^{9}$ In the present studies, each rat was injected with a total of $17 \mathrm{mg}$ monoclonal, high affinity immunoglobulin corresponding to an overall binding capacity of 256 glucagon eq/nM. The binding affinity for glucagon was calculated to be $7.2 \times 10^{10} \mathrm{M}^{-1}$ which is much higher than that for the hepatic rat glucagon receptor. This is reported to be $2.5 \times 10^{8} \mathrm{M}^{-1}$ which thus favours the binding of circulating glucagon to antibody rather than to the target organ receptor. ${ }^{32}$ Corresponding data for the different gut-GLIs are difficult to calculate, partly because of an inadequate supply of pure peptides and partly because their specific receptor binding sites are largely unknown. In the present study, the intravenous administration of porcine pancreatic glucagon, in a dose of $1.5 \mathrm{nmol}$, caused a significant increase in blood glucose concentration in the presence of plasmacytoma ascites but not in the presence of hybridoma ascites derived from clone 23.6B4. The abolition of the predicted effect of exogenous glucagon indicates that after administering the monoclonal antibodies, there must have been an efficient binding and neutralisation of pancreatic glucagon. Similar data have been reported for the neutralisation of exogeneous glucagon using polyclonal antiglucagon antisera. ${ }^{28-30}$ Again, corresponding experiments with the administration of exogenous gut GLIs must await the purification of sufficient quantities of these peptides.

The present results are a first indication that circulating enteroglucagon does not act as a trophic factor after small bowel resection. It does not however rule out a paracrine enterotrophic action of enteroglucagon, which might not be affected by the intravenous circulating monoclonal antibodies. Confirmation of our study on enteroglucagon deficiency in plasma using monoclonal antibodies must await the isolation and purification of sufficient quantities of enteroglucagon for in vivo infusion experiments and in vitro incubation studies. A supply of purified enteroglucagon would also allow us to identify the receptor binding site of enteroglucagon with regard to the antibody binding sites and to elucidate the structure function relationship. Such isolation studies of enteroglucagon are presently under way using monoclonal antibodies for high capacity immunoaffinity purification systems.

The work was supported by the Deutsche Forschungsgemeinschaft. (Gr 684/2-3)

\section{References}

1 Gleeson MH, Bloom SR, Polak JM, Henry K, Dowling RH. Endocrine tumor in kidney affecting small bowel structure, motility, and absorptive function. Gut 1971; 12: 773-82.

2 Bloom SR. An enteroglucagon tumor. Gut 1972; 13: 520-3.

3 Bloom SR, Polak JM. Enteroglucagon and the gut hormone profile of intestinal adaptation. In: Robinson JWL, Dowling RH, Riecken EO, eds. Mechanisms of intestinal adaptation. Lancaster: MTP Press, 1982: 18999.

4 Menge H, Robinson JWL. The relationship between the functional and structural alterations in the rat small intestine following proximal resection of varying extents. Res Exp Med (Berl) 1978; 173: 41-53.

5 Gregor M, Bryant MG, Buchan AMJ, Polak JM, Bloom SR. Effect of intestinal resection on colonic regulatory peptides in the rat. In: Robinson JWL, Dowling RH, Riecken EO, eds. Mechanisms of intestinal adaptation. Lancaster: MTP Press, 1982: 549-56.

6 Hanson WR, Osborne JW, Sharp JG. Compensation by the residual intestine after intestinal resection in the rat. I. Influence of amount of tissue removed. Gastroenterology 1977; 72: 692-700.

7 Bell GJ, Santerre RF, Mullenbach GT. Hamster preproglucagon contains the sequence of glucagon and two related peptides. Nature $1983 ; 302$ : 716-8.

8 Bell GJ, Sanchez-Pescador R, Layborn PJ, Najarian RC. Exon duplication and divergence in the human preproglucagon gene. Nature 1983; 304: 368-71.

9 Gregor M, Riecken EO. Production and characterization of N-terminally and $\mathrm{C}$-terminally directed monoclonal antibodies against pancreatic glucagon. Gastroenterology 1985; 89: 571-80.

10 Menge H, Hopert R, Alexopoulos T, Riecken EO. Three-dimensional structure and cell kinetics at different sites of rat intestinal remnants during the early adaptive response to resection. Res Exp Med (Berl) 1982; 181: 77-94.

11 Górnacz GE, Al-Mukhtar MYT, Ghatei MA, Sagor GR, Wright NA, Bloom SR. Pattern of cell proliferation and enteroglucagon response following small bowel resection in the rat. Digestion 1984; 29: 65-72.

12 Hanson WR, Osborne JW, Sharp JG. Compensation by the residual intestine after intestinal resection in the rat. II. Influence of postoperative time interval. Gastroenterology 1977; 72: 701-5.

13 Clarke RM. Mucosal architecture and epithelial cell 
production rate in the small intestine of the albino rat. $J$ Anat 1970; 107: 519-29.

14 Lorenz-Meyer H, Köhn R, Riecken EO. Vergleich verschiedener morphometrischer Methoden zur Erfassung der Schleimhautoberfläche des Rattendünndarmes und deren Beziehung zur Funktion. Histochemistry 1976; 49: 123-9.

15 Christofides ND, Bryant MG, Ghatei MA, Kishimoto S, Buchan AMJ, Polak JM, Bloom SR. Molecular forms of motilin in the mammalian and human gut and human plasma. Gastroenterology 1981; 80: 292-300.

16 Gregor M, Buchan AMJ, Riecken EO. Monoclonal antibodies to glucagon-like peptide 1 (GLP 1). Can J Phys Pharm 1986; 64: suppl. 75.

17 Gregor WH, Martin JM, Williamson JR, Lacy PE, Kipnis DM. A study of the diabetic syndrome produced in rats by anti-insulin serum. Diabetes $1963 ; 12: 73-81$.

18 Maruyama H, Tominaga M, Bolli G, Orci L, Unger RH. The alpha cell response to glucose change during perfusion of anti-insulin serum in pancreas isolated from normal rats. Diabetologia $1985 ; 28$ : 836-40.

19 Goyal RK, McGuigan JE. Is gastrin a major determinant of basal lower esophageal sphincter pressure? $J$ Clin Invest 1976; 57 : 291-300.

20 Villar HV, Watayou T, Booth RAD, Rayford PH, Reeder DD, Thompson JC. Suppression of gastric secretion and serum gastrin by gastrin antibody. Am J Surg 1976; 131 : 64-8.

21 Short GM, Doyle JW, Wolfe MM. Effect of antibodies to somatostatin on acid secretion and gastrin release by the isolated perfused rat stomach. Gastroenterology 1985; 88: 984-8.

22 Ebert R, Illmer K, Creutzfeldt W. Release of gastric inhibitory polypeptide (GIP) by intraduodenal acidification in rats and humans and abolishment of the incretin effect of acid by GIP-antiserum in rats. Gastroenterology 1979; 76: 515-23.
23 Lauritsen KB, Holst JJ, Moody AJ. Depression of insulin release by anti-GIP serum after oral glucose in rats. Scand J Gastroenterol 1981; 16: 417-21.

24 Ebert R, Creutzfeldt W. Influence of GIP antiserum on glucose-induced insulin secretion in rats. Endocrinology $1982 ; 111$ : 1601-6.

25 Ebert R, Unger H, Creutzfeldt W. Preservation of incretin activity after removal of gastric inhibitory polypeptide (GIP) from rat gut extracts by immunoadsorption. Diabetologia 1983; 24 : 449-54.

26 Wolfe MM, Hocking MP, Maico DG, McGuigan JE. Effects of antibodies to gastric inhibitory peptide on gastric acid secretion and gastrin release in the dog. Gastroenterology 1983; 84: 941-8.

27 Chey WY, Kim MS, Lee KY, Chang T. Effect of rabbit anti-secretin serum on postprandial pancreatic secretion in dogs. Gastroenterology 1979; $77: 1268-75$.

28 Frohman LA, Reichlin AM, Sokal JE. Immunological and biological properties of antibodies to a glucagonserum albumin polymer. Endocrinology 1970; 87: 105561.

29 Holst JJ, Galbo H, Richter EA. Neutralization of glucagon by antiserum as a tool in glucagon physiology. Lack of depression of basal blood glucose after antiserum treatment in rats. $J$ Clin Invest 1978 ; 62 : 18290.

30 Tan K, Tsiolakis D, Marks V. Effect of glucagon antibodies on plasma glucose, insulin and somatostatin in the fasting and fed rat. Diabetologia 1985; 28: 43540.

31 Wright LJ, Feinstein A, Heap RB, Saunders FC, Bennett RC, Wang M-Y. Progesterone monoclonal antibody blocks pregnancy in mice. Nature 1982; 295: 415-7.

32 Rodbell M, Kraus H, Pohl SL, Birnbaumer L. The glucagonsensitive adenyl cyclase system in plasma membranes of rat liver. $J$ Biol Chem 1971; 246: 186171. 